\title{
Correction to: Integrative study of EZH2 mutational status, copy number, protein expression and H3K27 trimethylation in AML/ MDS patients
}

Julia Stomper ${ }^{1 \dagger}$, Ruth Meier ${ }^{1 \dagger}$, Tobias Ma ${ }^{1}$, Dietmar Pfeifer ${ }^{1}$, Gabriele Ihorst $^{2}$, Nadja Blagitko-Dorfs ${ }^{3}$, Gabriele Greve ${ }^{1}$, Dennis Zimmer ${ }^{1}$, Uwe Platzbecker ${ }^{4,5}$, Anne Hagemeijer ${ }^{6}$, Ingrid Schmitt-Graeff ${ }^{7}$ and Michael Lübbert ${ }^{1,8,9^{*}}$ (1)

\section{Correction to: Clin Epigenet (2021) 13:77 https://doi.org/10.1186/s13148-021-01052- 2}

After publication of the original article [1], the authors identified an error in the author name of Schmitt-Graeff.

The incorrect author's name is: Annette Schmitt-Gräf.

The correct author's name is: Ingrid Schmitt-Graeff.

The author group has been updated above and the original article [1] has been corrected.

\section{Author details}

'Department of Medicine I (Hematology, Oncology and Stem Cell Transplantation), Medical Center - University of Freiburg, Freiburg, Germany. ${ }^{2}$ Clinical Trials Unit, Faculty of Medicine, Medical Center - University of Freiburg, Freiburg, Germany. ${ }^{3}$ Institute for Immunodeficiency, Center for Chronic Immunodeficiency (CCl), Medical Center - University of Freiburg, Freiburg, Germany. ${ }^{4} \mathrm{Ger}-$ man Cancer Consortium (DKTK) and German Cancer Research Center (DKFZ), Partner Site Dresden, Dresden, Germany. ${ }^{5}$ Medical Department-Hematology and Cell Therapy, Medical Oncology, Hemostaseology, University of Leipzig Medical Center, Leipzig, Germany. ${ }^{6}$ University of Leuven, Leuven, Belgium. ${ }^{7}$ University of Freiburg, Freiburg, Germany. ${ }^{8}$ German Cancer Consortium (DKTK) and German Cancer Research Center (DKFZ), Partner Site Freiburg,
Freiburg, Germany ${ }^{9}$ Faculty of Medicine, University of Freiburg, Freiburg, Germany.

Published online: 28 April 2021

Reference

1. Stomper et al. Clin Epigenet. 2021;13:77. https://doi.org/10.1186/ s13148-021-01052-2.

\section{Publisher's Note}

Springer Nature remains neutral with regard to jurisdictional claims in published maps and institutional affiliations.

The original article can be found online at https://doi.org/10.1186/s13148021-01052-2.

*Correspondence: michael.luebbert@uniklinik-freiburg.de

† Julia Stomper and Ruth Meier have contributed equally to this work.

${ }^{1}$ Department of Medicine I (Hematology, Oncology and Stem Cell

Transplantation), Medical Center - University of Freiburg, Freiburg, Germany

Full list of author information is available at the end of the article

(c) The Author(s) 2021. Open Access This article is licensed under a Creative Commons Attribution 4.0 International License, which permits use, sharing, adaptation, distribution and reproduction in any medium or format, as long as you give appropriate credit to the original author(s) and the source, provide a link to the Creative Commons licence, and indicate if changes were made. The images or other third party material in this article are included in the article's Creative Commons licence, unless indicated otherwise in a credit line to the material. If material is not included in the article's Creative Commons licence and your intended use is not permitted by statutory regulation or exceeds the permitted use, you will need to obtain permission directly from the copyright holder. To view a copy of this licence, visit http://creativecommons.org/licenses/by/4.0/. The Creative Commons Public Domain Dedication waiver (http://creativeco mmons.org/publicdomain/zero/1.0/) applies to the data made available in this article, unless otherwise stated in a credit line to the data. 